UDC: $342.8: 061.2(100)$

\title{
International NGOs as Actors of Electoral Governance
}

\author{
Nikolai Grishin \\ Professor, Saint Petersburg State University \\ E-mail: nvgrishin@mail.ru \\ Anna Maria R. Leenders \\ Lecturer, MGIMO - University of the Ministry of Foreign Affairs of Russia \\ E-mail: leenders.a.m@my.mgimo.ru
}

\begin{abstract}
The paper discusses the process of formation and development of non-governmental international organizations operating in the field of elections. The classification of these organizations by levels and areas of activity is proposed. The main focus of these types of actors is election observation. The role of Russia in the development of international non-governmental organizations in the field of elections is revealed. The part of particular leading actors, primarily the Global Network of National Election Observers, is defined. The conclusion was reached that the connection of these organizations with certain countries is weakening, while their support from other international actors is increasing. It is determined that at the present stage, non-governmental organizations can influence the organization of the electoral process, bypassing the national level of government and having a direct impact on international structures.
\end{abstract}

Keywords: electoral politics, electoral governance, global governance, electoral studies, international NGOs, election observation

\section{Introduction}

At the turn of the $21^{\text {st }}$ centuries, new types of international actors emerged that influence the organization and conduct of elections, including such actors as international inter-governmental and non-governmental organizations, think tanks and analytical centers.

The international level of electoral governance includes several types of actors. During the $20^{\text {th }}$ century, the only type of such actors was international intergovernmental organizations. At the present stage, international non-governmental organizations is growing and promising new kind of global electoral governance actor.

The participation of international non-governmental organizations in election governance at the international level is a tragically underdeveloped field in the research agenda. To fill this gap, the paper presents a picture of this aspect of electoral governance and global politics.

We assume that the increasing role of the international community in organizing 
elections is part of the fundamental processes of globalization and is determined by the modern evolution of forms of governance. It is necessary to study and comprehend the prospects, opportunities and limits of international actors in electoral governance. For the first time, this phenomenon should be considered as one of the areas of global governance and, obviously, as the most significant field of the international community's influence on political processes.

In the 2010s in the scientific literature there has been a tendency towards a more holistic and integrated consideration of the role of the international factor in the organization of elections. This can be judged by the largest modern scientific project on electoral issues - the "Electoral Integrity Project" headed by P. Norris, namely, chapters in the monographs "Advancing Electoral Integrity", "Election Watchdogs"2, "Strengthening Electoral Integrity"3.

At the present stage of studies of the international factor in electoral politics, certain methodological attitudes are traced. In Russian science, the role of the international community in organizing and conducting elections is considered almost exclusively within the framework of the state-centrist approach. While studying this field, the capabilities of modern methodological approaches to the study of global governance, as well as the network approach, etc., have not yet been used.

One of the first significant non-governmental organizations to become active at the international level was the International Foundation for Electoral Systems (IFES), founded in 1987. Throughout its history, the IFES has worked to promote elections in 145 countries, and currently has programs in more than 20 countries. The organization has the following main areas of work: 1) providing technical assistance to election bodies; 2) assistance to entities whose representation in the election process is limited, 3) conducting field research to optimize the organization of elections. This organization has been playing a paramount role in supporting and developing other election support organizations around the world ${ }^{4}$.

The existing variety of international non-governmental organizations operating in the field of elections can be classified on various grounds. Firstly, they could be classified depending on whether they are global or tied to particular regions (for example, Europe). Secondly, organizations can be classified depending on the specific direction of their activities 5 .

\footnotetext{
${ }^{1}$ Norris P., Frank R., Coma F (eds.), Advancing Electoral Integrity, Oxford University Press, Oxford, 2014.

2 Norris P., Nai A. (eds.), Election Watchdogs, Oxford University Press, Oxford, 2017.

${ }^{3}$ Norris P., Strengthening Electoral Integrity, Cambridge University Press, 2017.

${ }^{4}$ Darnolf, S., International election support: Helping or hindering democratic elections? Representation, 2011, 47(4), pp. 361-382.

5 Borzyskowski, I. , Resisting democracy assistance: Who seeks and receives technical election assistance? The Review of International Organizations, 2016, 11(2), pp. 247-282.
} 


\section{Prospects for a Network Approach to Studying the Role of International Organizations in Electoral Governance}

The network approach, despite the long history of application in the political sciences, was hardly used in the study of election governance. The only exception is the leading British electoral administration researcher Toby S. James.

Toby S. James identifies five main types of governance networks in electoral management, the first three of which exist in countries of sustainable democracy:

* Mature governmental network, in which the election is responsible mainly for one authority with minimal participation of other actors.

* Asymmetric network, in which many entities are involved in the organization of elections, there is a possibility of pressure from civil society, including political parties, but the priority belongs to state bodies.

* The Pluralistic collaborative network, in which a wider range of government bodies are open to interact with civil society, the possibilities for the executive branch are more limited.

* The following two types of governance networks are characteristic of electoral management of non-democratic countries:

* Closed statist systems, in which a narrow circle of actors is involved in organizing elections in an authoritarian regime.

* Contested closed systems, which exist under electoral authoritarianism.

This typology was developed by Toby James to interpret models of election governance at the level of nation-states ${ }^{6}$. It was not used to review electoral governance at the international level. Only one of these five types of governance networks, the pluralistic network of cooperation, can correspond to the international level of electoral governance. Only this model corresponds to the degree of coordination relations that are characteristic of international cooperation in the field of election regulation.

The network approach makes it possible to identify and reflect the special ontological properties of electoral governance at the international level. The participation of the international community in this sphere of governance is based on the principles of a heterarchy and extremely high independence of actors. The totality of international actors involved in the regulation of elections makes up a community that does not meet the parameters of full networks.

\section{Regional Networks of Independent Election Support Organizations}

Most of international non-governmental elections support organizations have a regional status, and Europe has the most of these organizations. The most significant pan-European public organizations active in the field of elections are the following:

* European Centre for Electoral Support (ECES);

\footnotetext{
6 James, T., Assessing the independence of electoral management boards: A policy network approach, Paper for the American Political Science Conference, San Francisco, 2015.
} 
* ACE Electoral Knowledge Network;

* European Network of Election Monitoring Organizations (ENEMO);

* European Platform for Democratic Elections (EPDE);

* Spinelli Group;

* European Partnership for Democracy (EPD);

* VoteWatch Europe

European Centre for Electoral Support (ECES) is active and influential panEuropean NGO. It is a not for profit private foundation headquartered in Brussels with a global remit. ECES promotes sustainable democratic development through the provision of advisory services, operational support and management of large projects in the electoral and democracy assistance field. ECES works with all electoral stakeholders, including electoral management bodies, civil society organizations involved in voter education and election observation, political parties, parliaments, media, etcetera ${ }^{7}$.

Among these organizations the ACE Electoral Knowledge Network stands out in form. The ACE Electoral Knowledge Network is the unique kind of actor. Originally created in 1998 as an Internet project (ACE Project), it subsequently acquired the status of a permanent expert online community. The organization is completely decentralized and it operates only online. The International Institute for Democracy and Electoral Assistance (IDEA), the IFES, the United Nations Department of Economic and Social Affairs (UNDESA) take part in ensuring its activities. The ACE Electoral Knowledge Network plays an outstanding role in the study of contemporary electoral politics, the development of modern electoral standards, and the preparation of recommendations for the development of electoral institutions.

In Africa, the leading international public organizations dealing with election issues are:

* Electoral Institute for Sustainable Democracy in Africa (EISA)

* Electoral Support Network of Southern Africa (ESN-SA) - former SADC Electoral Support Network (SADC ESN)

* Electoral Knowledge Network of the Central African States (RESEAC)

* The African Elections Observers Network (AfEONet)

* West Africa Election Observers Network (WAEON)

* East and Horn of Africa Election Observers Network (E-HORN).

The Electoral Institute for Sustainable Democracy in Africa (EISA) is an independent, non-profit non-partisan nongovernmental organization whose focus is elections, democracy and governance in Africa. It was established in 1996, based in Johannesburg (South Africa) with field offices across the continent. In 2018 EISA had 7 field offices, namely, Democratic Republic of the Congo (DRC), Madagascar,

7 ECES. A European response to electoral cycle support (EURECS). URL: http://www.eces.eu/en/ posts/eurecs (accessed 30.04.2020) 
Mali, Mozambique, Somalia, and Zimbabwe and a Central Africa regional office (Gabon) $)^{8}$. EISA engages in mutually beneficial capacity reinforcement activities aimed at enhancing all partners' interventions in the areas of elections, democracy and governance. EISA continued to play a role in strengthening democratic electoral processes providing support to regional bodies, civil society organizations in election observation. In regard to support to election management bodies, EISA provide technical support and advice to EMBs.

Other international NGOs on the African continent focus on election observation. The West Africa Election Observers Network (WAEON) is an independent, nonpartisan and non-religious organization that aims at strengthening and supporting citizens' election observation groups in the sub-region. WAEON comprises independent and non-partisan citizens' election observation groups in West Africa that subscribe to the Declaration of Global Principles for Non-partisan Election Observation and Monitoring by Citizen Organizations. Established in 2010, the network seeks to strengthen the technical capacities and provide moral support to member organizations to conduct non-partisan citizen election observation, champion electoral reform and advocacy to promote credible elections in their respective countries ${ }^{9}$.

The African Elections Observers Network (AfEONet) includes other two regional associations: West Africa Election Observers Network (WAEON) and East and Horn of Africa Election Observers Network (E-HORN).

\section{Russia's Contribution to the Development of International Elections Support NGOs}

Russia also made its contribution to the development of a network of nongovernmental public organizations operating in the field of elections. Firstly, in 2003, at the initiative of the Russian leadership, there was established the CIS-EMO (Commonwealth of Independent States - Election Monitoring Organization). The CIS-EMO was aimed at conducting election observation in the CSTO countries. Since its inception, the organization has been an important tool for supporting some candidates in the CIS. The organization had been active until 2012: the suspension of its activities was not officially reported.

Russia's contribution to the development of international electoral support organizations also lies in the fact that the Voice Association (Russian election observation independent NGO) was one of the founders of the EPDE in 2012. But in 2018 EPDE was included in the list of undesirable foreign and international organizations by Russia's Ministry of Justice.

\footnotetext{
${ }^{8}$ EISA. Annual report 2018. URL: https://www.eisa.org.za/pdf/AR2018.pdf (accessed 30.04.2020)

${ }^{9}$ WAEON. A Field Guide for West Africa Election Observers Network URL: http://waeon.org/libresources.php (accessed 30.04.2020)
} 


\section{Election Observation as the Main Field of International Non- Governmental Elections Support Organizations}

Election observation is the main field of activity for a significant number of international election support organizations ${ }^{10}$. In this field of activity, a huge and structured network of international organizations has been created, which is a significant force in contemporary global electoral governance ${ }^{11}$. The first such international organization, the Asian Network for Free Elections (ANFREL), was created in 1997 as a regional association of election observation NGOs from different Asian countries. Currently, it includes 26 organizations from 16 states.

In 2001, a similar association was created in Europe. The European Network of Election Monitoring Organizations (ENEMO) includes 23 non-profit election observation organizations from 18 countries. The ENEMO not only ensures the interaction of the founding organizations, but also monitors elections in different countries (23 election observation missions have taken place to date) and over the course of its existence it has trained more than two hundred thousand observers.

In 2009, about two hundred public election support organizations from eighty countries created the international public organization: The Global Network of Domestic Election Monitors (GNDEM). To date, two hundred and fifty national and regional public organizations from eighty-nine countries and five continents have already participating in this association. From Russia, the Voice Association is participating in the activities of the GNDEM. In addition, this association enjoys the support of the most influential international intergovernmental organizations. It is the most visible and significant global NGO operating in the sphere of elections ${ }^{12}$.

The Global Network of Domestic Election Monitors has initiated the preparation of the first international documents related to the issues of non-partisan independent election monitoring.

In 2012, the Declaration of Global Principles for Nonpartisan Election Observation and Monitoring by Citizen Organizations was proclaimed in the UN Headquarters. The declaration is a set of important criteria for self-monitoring and reporting by organizations that exercise non-partisan control over elections. It provides a basis for mutual understanding on which non-partisan organizations can build their relations with members of election commissions and various government departments. It also provides an opportunity for the public, news media and interested

${ }^{10}$ Kelley, J. , D-Minus Elections: The Politics and Norms of International Election Observation, International Organization, 2009, 63(04), pp. 765.

11 Hyde, S. D., Catch Us If You Can: Election Monitoring and International Norm Diffusion, American Journal of Political Science, 2011, 55(2), pp. 356-369.

12 Hyde, S. D., Marinov, N., Information and Self-Enforcing Democracy: The Role of International Election Observation, International Organization, 2014, 68(02), pp. 329-359. 
members of the international community to better understand the role and tasks of organizations sharing the Declaration of Global Principles. The declaration sets out the basic principles and explains the need for public action to observe the elections in order to ensure their transparency. It defines the types of activities and formulates moral obligations regarding impartiality, independence, accuracy, transparency, non-discrimination, respect for the law and cooperation with various stakeholders of electoral process and international observers. It describes the processes to be monitored and the conditions for successful non-partisan public monitoring of the electoral process. At the same time, in 2012, the Code of Conduct for Non-Party Public Election Observers was proclaimed at UN Headquarters. The Declaration of Global Principles for Nonpartisan Election Observation and Monitoring by Citizen Organization was signed by one hundred and sixty non-political public organizations from seventy five countries of the world. It was supported by thirteen international organizations and entities, including intergovernmental organizations such as the Venice Commission of the Council of Europe, the OSCE / ODIHR, and the United Nations Secretariat.

Thus, international election observation NGOs constitute a multilevel structure. For African organizations, this structure is three-tier: a domestic election observation NGO can participate in a regional association, for example, in the Electoral Support Network of Southern Africa (ESN-SA), which participates in the continental association African Elections Observers Network (AfEONet), which participates in the Global Network of Domestic Election Monitors (GNDEM).

\section{Political Controversies of the International Participation in Electoral Governance}

The role of international organizations in regulating the electoral processes of states is changing. There is a clear tendency to expand their functions. Over the past quarter century, the active practice of international election assistance has substantially changed the content of this work. Its episodic character, which prevailed at an early stage, in the 2000 s is replaced by a long-term and systematic approach. The list of electoral process issues that have come to the attention of international actors is expanding. In the $21^{\text {st }}$ century particular international organizations significantly expanded the very concept of "electoral assistance" and begin to put into practice the principle of international responsibility for ensuring honest and fair elections.

Initially, the work of most international organizations is focused on special attention to countries in which there was no experience of sustainable democracy and which objectively needed appropriate assistance. However, the prolonged (over several decades) custody of developed democracies over questions of the domestic politics of the countries of "new democracy" cannot but cause doubts. There is a clear imbalance in the work of international organizations that control elections. The focus is precisely on the former socialist and developing countries. In countries where 
democracy is stable, control over the electoral process is exercised to a much lesser extent. Such practices may seem unfair and biased. Some politicians interpret it as humiliating for the country and violating its sovereignty.

The practice of "double standards" is also controversial - the various requirements for organizing elections in Western democracies and countries with new democratic forms of governance. An example is the position of the European organizations that recommend holding elections by independent election commissions for former socialist countries, whereas for developed democracies, such a requirement is recognized as optional.

\section{Conclusion}

It can be assumed that if the first international public organizations in the field of elections had a strong relationship with a certain country (primarily with the USA), then in the $21^{\text {st }}$ century they become more international and correspond to the principles of global governance. Their connection with certain countries is weakening. The support of these actors from other actors of global governance is growing. They enjoy support by intergovernmental organizations (in particular, the UN, European structures) and different kinds of international non-governmental organizations. Since the international election support NGOs can influence the international practice of elections, bypassing the level of national governance, their development further contributes to the weakening of the role of nation-states in the system of electoral governance.

\section{Funding}

The reported study was funded by RFBR according to the research project № 19-011-00484. 